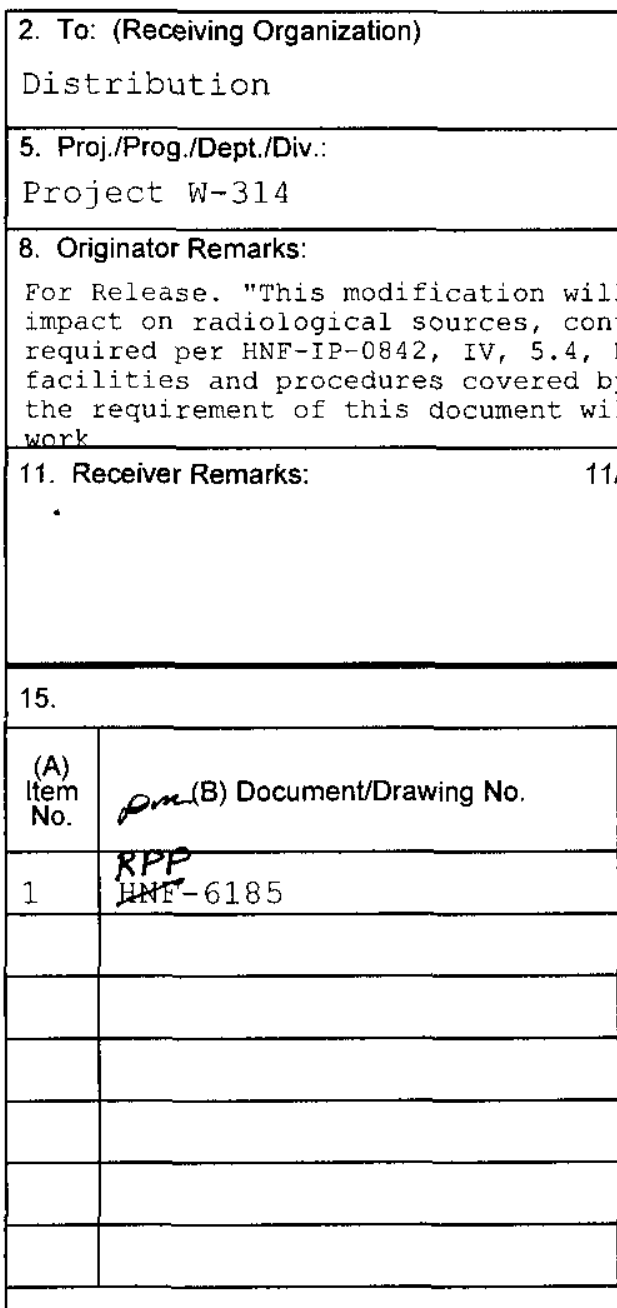

\section{Originator Remarks:} work

11. Receiver Remarks:

3. From: (Originating Organization)
TFR\&SO
$\begin{aligned} & \text { 6. Design Authority/Design Agent/Cog. Engr.: } \\ & \text { D. E. Bowers }\end{aligned}$

D. E. Bowers not increase collective dose since it has no

11A. Design Baseline Document? $\square$ Yes $\square$ No

\begin{tabular}{l} 
4. Related EDT No.: \\
N/A \\
7. Purchase Order No:: \\
N/A \\
\hline 9. Equip./Component No.:
\end{tabular}

$\mathrm{N} / \mathrm{A}$

10. System/Bldg./Facility:

$\mathrm{N} / \mathrm{A}$

12. Major Assm. Dwg. No.:

$\mathrm{N} / \mathrm{A}$

13. Permit/Permit Application No:

$\mathrm{N} / \mathrm{A}$

14. Required Response Date:

$\mathrm{N} / \mathrm{A}$

\section{DATA TRANSMITTED}

\begin{tabular}{c|c|c}
$\begin{array}{l}\text { (C) Sheet } \\
\text { No. }\end{array}$ & (D) Rev. \\
No. & (E) Title or Description of Data Transmitted
\end{tabular}

(F)

(G)

(H)

(I)

Approval Reason Origi- Receiv-

Approval Reason nator Receiv-

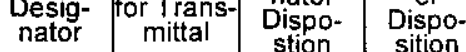

\begin{tabular}{|c|c|c|c|} 
nator & mittal & stion & sition \\
\hline ESQ & & & \\
\hline & & & \\
\hline
\end{tabular}

16.

\begin{tabular}{|c|l|}
\hline Approval Designator $(F)$ & \\
\hline$E, S, Q, D$ OR N/A & 1. Approval \\
(See WHC-CM-3-5, & 2. Release \\
Sec. 12.7) & 3. Information \\
\hline
\end{tabular}

17.

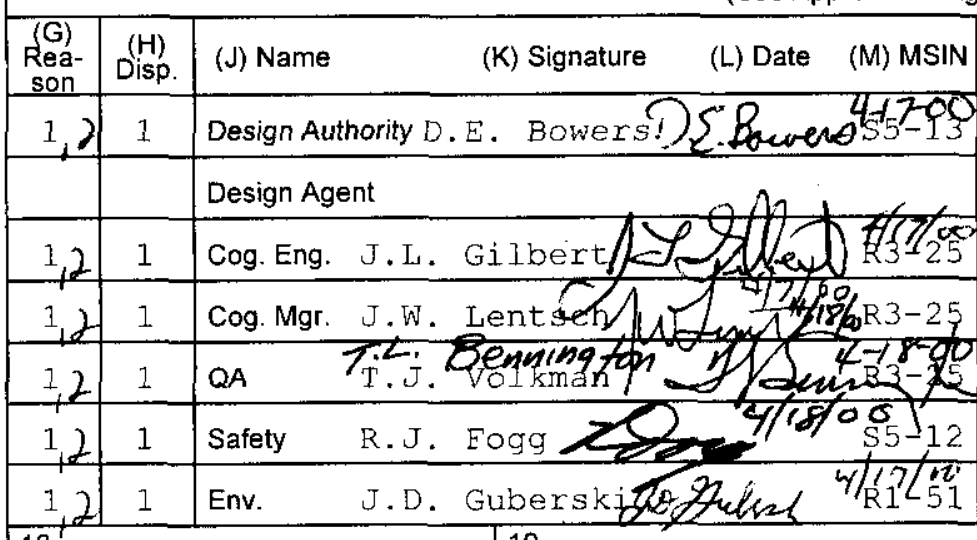
18.

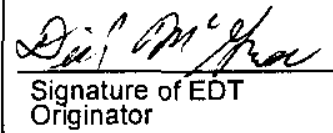
4YED Date Authorized Representative for Receiving Organization
Reason for Transmittal (G)

4. Review

5. Post-Review

6. Dist. (Receipt Acknow. Required)
KEY
SIGNATURE/DISTRIBUTION
(See Approval Designator for required signatures)

\section{Approved
2. Approved w/comment \\ 4. Reviewed no/comment 5. Reviewed w/comment \\ 6. Receipt acknowledged}

Disposition $(\mathrm{H})$ \& (I)

\begin{tabular}{|c|c|c|}
$\begin{array}{c}\text { Rea- } \\
\text { son }\end{array}$ & $\begin{array}{c}(\mathrm{H}) \\
\text { Disp. }\end{array}$ \\
\hline 1,2 & 1 & \\
\hline 12 & 1 & \\
\hline & & \\
\hline & & \\
\hline & & \\
\hline & & \\
\hline
\end{tabular}

20.

(J) Name

(K) Signature

(L) Date

(M) MSIN 


\title{
Systems Engineering Management Plan for Tank Farm Restoration and Safe Operations, Project W-314
}

\author{
D. L. NoGrow \\ Numatec Hanford Corporation \\ Richland, WA 99352 \\ U.S. Department of Energy Contract DE-AC06-96RL13200
}
EDT/ECN: $628193 \quad$ UC:
Org Code: 7C300 Charge Code: 109749
B\&R Code: Total Pages: 34

Key Words: Systems Engineering Management Plan, Project W-314, Tank Farm Restoration and Safe Operations, Office of River Protection

Abstract: The systems Engineering Management Plan for Project $W-314$ has been prepared within the guidelines of HNF-SD-WM-SEMP-002, TWRS Systems Engineering Management Plan. The activities within this SEMP have been tailored, in accordance with the TWRS SEMP and DOE Order 430.1, Life Cycle Asset Management, to meet the needs of the project.

TRADEMARK DISCLAIMER. Reference herein to any specific commercial product, process, or service by trade name, trademark, manufacturer, or otherwibe, does not necesearly constitute or imply its endorsement, recommendation, or kavoring by the United States Government or any agency thereof or its contractors or subcontractors.

Printed in the United States of America. To obtain coples of this document, contact: Document Control Services, P.O. Box 950, Mailutop H6-08, Richland WA 99352, Phone (509) 372-2420; Fax (509) 376-4989.

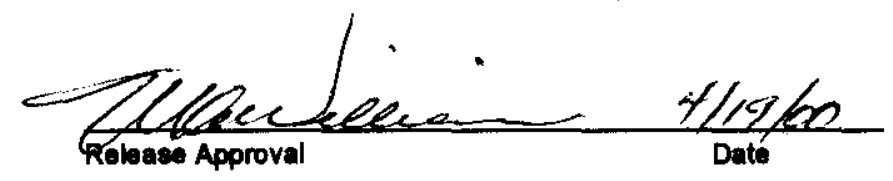

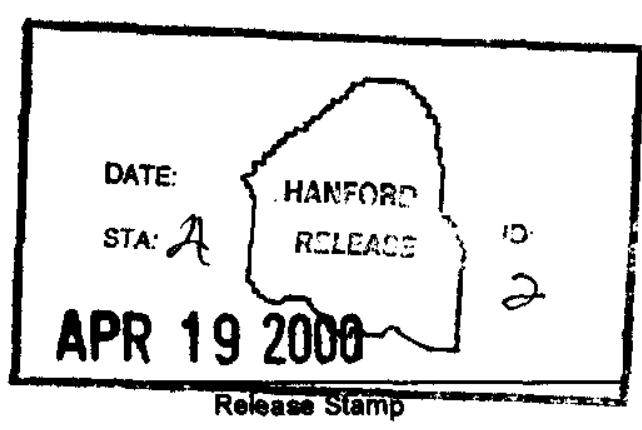

Approved For Public Release 


\section{SYSTEMS ENGINEERING MANAGEMENT PLAN}

For

TANK FARM RESTORATION

AND SAFE OPERATIONS

\section{PROJECT W-314}

Prepared for

U.S. Department of Energy

Office of River Protection

by

CH2M HILL Hanford Group, Inc.

Revised

April 2000 


\section{TABLE OF CONTENTS}

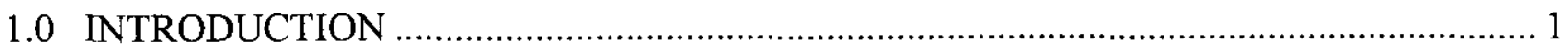

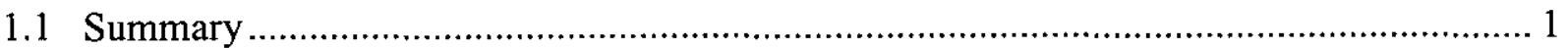

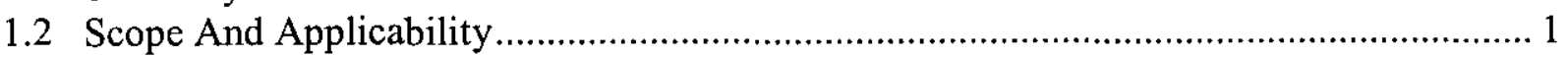

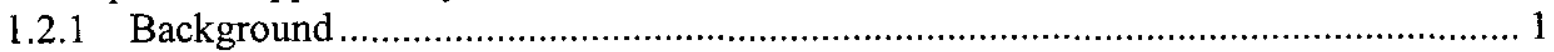

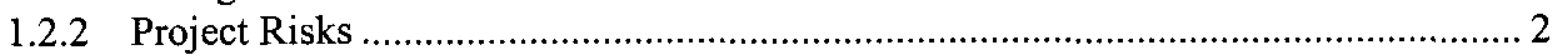

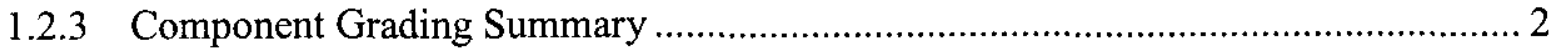

1.2.4 Interface with Other Planning Documents..................................................... 3

2.0 SYSTEMS ENGINEERING MANAGEMENT PROCESSES …................................ 3

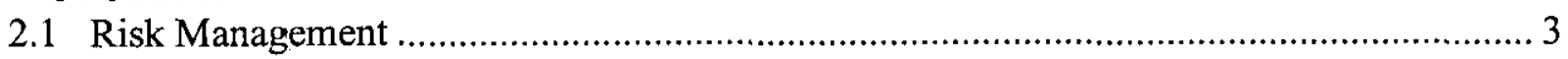

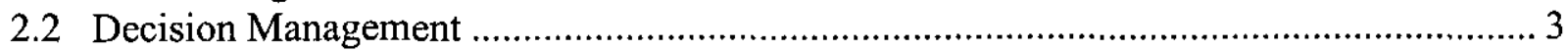

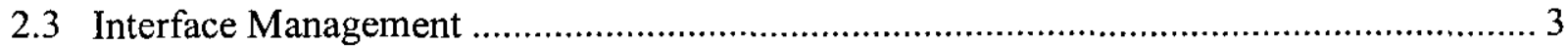

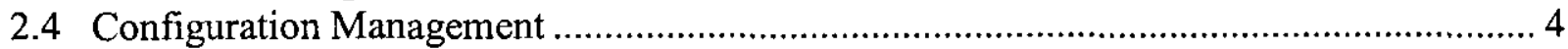

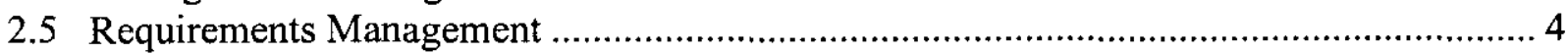

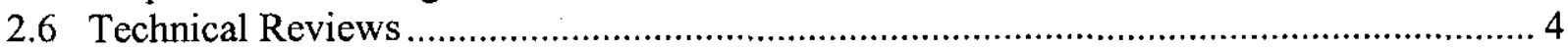

2.6.1 Preliminary Design Reviews........................................................................ 4

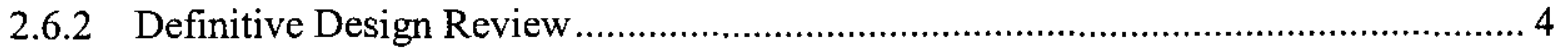

3.0 SYSTEMS ENGINEERING PROCESS AND PRODUCTS …................................ 4

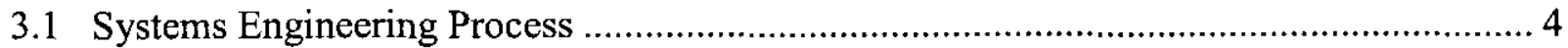

3.1.1 Mission Analysis................................................................................... 5

3.1.2 Functions and Requirements Analysis and Allocation ....................................... 5

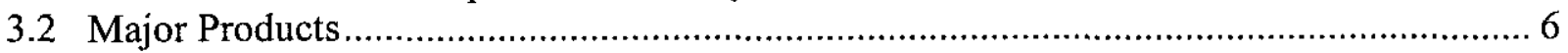

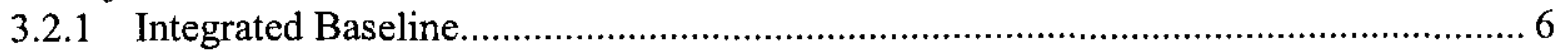

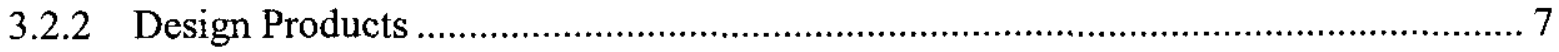

3.2.3 Alternative Generation and Architecture Selection ......................................... 9

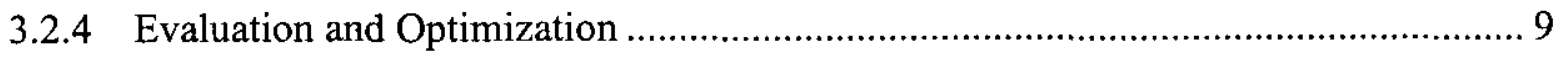

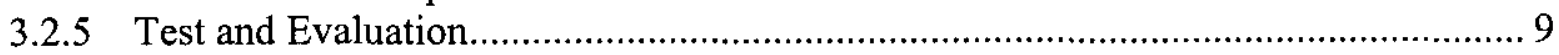

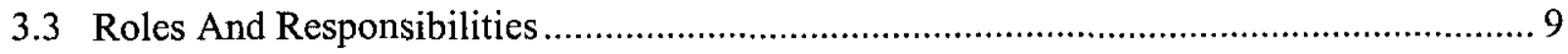

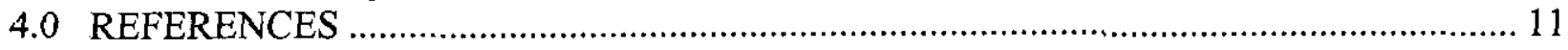

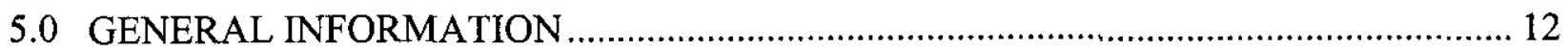

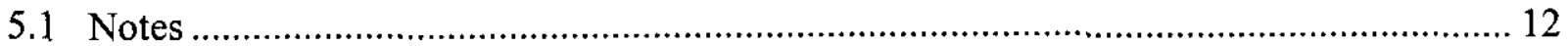

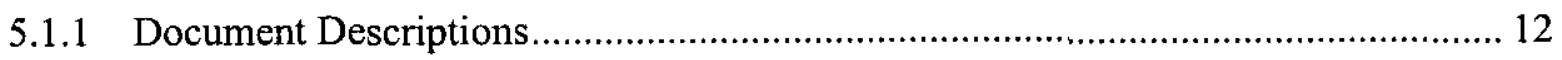

\section{LIST OF TABLES}

Table 3-1: CHG Design Approval Authorities .................................................................. 10

\section{LIST OF APPENDICES}

Appendix A: Graded Systems Engineering Approach for Project W-314 ...................................A-1

Appendix B: Project Development Specification (PDS) Standard for Project W-314 …............... B-1 


\begin{tabular}{ll} 
Acronyms and Abbreviations \\
ABU & Acceptance for Beneficial Use \\
AGA & Alternative Generation Analysis \\
CD & Critical Decision \\
CM & Configuration Management \\
COTS & commercial off-the-shelf \\
D\&D & Deactivation and Decommissioning \\
DCBL & Design Configuration Baseline \\
DDR & Detailed Design Review \\
DOE & Department of Energy \\
DRD & Design Requirements Document \\
F\&R & Functions and Requirements \\
FFBD & Functional Flow Block Diagram \\
FRAT & Functions, Requirements, Architecture and Test \\
I\&C & Instrumentation and Control \\
ICD & Interface Control Drawing \\
ICWG & Interface Control Working Group \\
MMI & Man-Machine Interface \\
MPS & Master Pump Shutdown system \\
P\&ID & Piping and Instrumentation Drawing \\
PDC & Project Design Concept document \\
PDR & Preliminary Design Review \\
PDS & Project Development Specification \\
PICD & Project Interface Control Document \\
PLC & Programmable Logic Controller \\
RL & DOE Richland Operations \\
RSO & Retrieval Support Operations \\
SE & Systems Engineering \\
SEMP & Systems Engineering Management Plan \\
SSC & Systems, Structures and Components \\
STEP & Specific Test and Evaluation Plan \\
TEP & Test and Evaluation Plan \\
TFLAN & Tank Farm Local Area Network \\
TPM & Technical Performance Measurement \\
TFO & Tank Farm Operations \\
TSEP & TWRS Systems Engineering Procedure \\
TWRS & Tank Waste Remediation System \\
V\&V & Verification and Validation \\
\hline
\end{tabular}




\subsection{INTRODUCTION}

Project W-314 is a fiscal year 1997 project within the Tank Waste Remediation System (TWRS) (recently re-named River Protection Project (RPP)) strategic system. This Systems Engineering Management Plan (SEMP) has been prepared within the guidelines of the HNF-SD-WM-SEMP002, TWRS Systems Engineering Management Plan (TWRS SEMP) and the outline provided by the Tank Waste Retrieval System Engineering Management Plan Implementation, (H.L. Boston, 1998). The activities specified within this SEMP have been tailored in accordance with the TWRS SEMP and DOE Order 430.1, Life Cycle Asset Management to meet the needs of the project.

The mission of this project is to provide upgrades to the existing waste transfer, electrical, ventilation, instrumentation and control systems, in support of the Office of River Protection (ORP) and continued management of Hanford tank wastes. The goal of the ORP is to develop the capability within private industry to vitrify tank farm waste at Hanford. A more thorough explanation of this project is contained in HNF-SD-W314-PMP-001, Project Execution Plan for Tank Farm Restoration and Safe Operations, Project W-314 (W-314 PEP). Specific equipment to be addressed by this project is listed in HNF-SD-W314-DRD-001, Preliminary Design Requirements Document for Project W-314, Tank Farm Restoration and Safe Operations (DRD).

\subsection{Summary}

This Systems Engineering Management Plan (SEMP) describes the processes, products, and organizational responsibilities implemented by Project W-314 to further define how the project's mission will be accomplished using guidance provided by the TWRS SEMP. As W-314 is an ongoing project, which completed CD-1 prior to October 1997, the project will migrate W-314 systems engineering practices as necessary, and as practicable, to be consistent with the TWRS SEMP for technical baseline development based on risk associated with the maturity of the W314 systems and budget constraints. The purpose of this SEMP is to identify and plan the requirements development and design activities needed for completion of design, construction, startup and turnover of the hardware upgraded by Project W-314. This document supplements the Project Execution Plan technical activity planning.

\subsection{Scope And Applicability}

This SEMP applies to the technical activities for Project W-314, including subcontracts, throughout the project life cycle from conceptual design through construction, and startup/turnover for items within the project scope. This SEMP communicates the project specific planning for implementing systems engineering as defined in the TWRS SEMP.

Where existing plans and procedures exist, those documents are referenced herein.

\subsubsection{Background}

Project W-314 will provide upgrades to existing equipment or replacement of equipment as delineated in the DRD. The upgrade activities are divided into a 2-phased approach. Details of the scoped items and associated products for each phase are provided in Appendix A. 
Phase 1 of this project develops, constructs, and tests the equipment for waste retrieval. Phase 2 provides equipment upgrades for environmental compliance. The Project W-314 scope has been grouped into design packages by location per the project Work Breakdown Structure in the W314 PEP.

Each phase has four major activities: requirement definition; design; construction; and testing/turnover for operations. For the requirement definition activity, Project Development Specifications (PDSs) will be developed. They will contain the performance, interface, verification and constraining requirements for each end item. After these documents are approved, they will be used during the design activity to generate and verify each end item design. The development of each design package has been staggered in time. After the start of construction, the W-314 systems engineering activities will be focused on monitoring design verification processes (test, demonstration, examination), monitoring Engineering Change Notices for potential negative impacts to the system's previously verified functionality and performance characteristics, and interface control issues resolution.

\subsubsection{Project Risks}

Specific W-314 Project risks are documented in the "W-314 Risk Management List" and are managed as outlined in RPP-6160, Risk Management Plan for Tank Farm Restoration and Safe Operations Project $W-314$ (W-314 RMP).

\subsubsection{Component Grading Summary}

The screening process to determine the category of implementation of systems engineering is defined per the TWRS SEMP (Rev. 1). The Project W-314 risk grading is stated in Appendix A as "moderate". A SE Category 1 project is a system modification, which has high or moderate risk/complexity, and thus corresponding SE activities and products are required.

Although there is a single SE level for the project, the required activities and products were tailored for each end item based on complexity, mission criticality and safety significance. Required products are identified in Appendix A of this SEMP. If the product is not required, then the activity which generates it is also not required.

As the required products were based on TWRS SEMP (Rev. 0), the following summary is provided to show product equivalence between the on-going project and the current TWRS guidelines. A more complete description of the W-314 documents can be found in section 5.1.1, "Document Descriptions" of this SEMP.

DRD- a Design Requirements Document is considered equivalent to a Level 1 Specification as defined in the current TWRS SEMP (Rev 1) and contains system-level requirements for the Project. The W-314 DRD was prepared by the W-314 Project and approved by both WHC and DOE/RL in late 1996. 
PDS - a Project Development Specification is considered equivalent to the Project Design Criteria document derived from the Level 2 Specifications as defined in the current TWRS SEMP (Rev 1). The PDS contains design requirements for a specific Project W-314 subsystem or component. Appendix B, of this SEMP, provides a universal PDS format.

PDC- A Project Design Concept prepared by the W-314 Project contains a description of the W-314 system operational concepts, conceptual end item layouts or conceptual illustrations, user interface descriptions and any other qualitative information necessary to communicate evolving operational and design concepts to designers and operators.

PICD- a Project Interface Control Document is equivalent to an Interface Control Document as defined in the current TWRS SEMP (Rev 1) and is used to document specific design interface agreements between physical interfaces and a description of the physical characteristics of the interface.

\subsubsection{Interface with Other Planning Documents}

This SEMP is intended to delineate the systems engineering aspects of the project and support the W-314 PEP technical activity planning.

\subsection{SYSTEMS ENGINEERING MANAGEMENT PROCESSES}

\subsection{Risk Management}

Risk methodologies are discussed in the W-314 RMP. A periodically updated Risk Management List will be generated for use by the project management team.

\subsection{Decision Management}

Project decisions, which could have a significant impact on the project, will follow procedure HNF-IP-0842, Vol. IV, Section 2.7, Decision Management, as applicable.

\subsection{Interface Management}

Design interfaces between the W-314 Project equipment and either existing equipment or equipment to be provided by other activities will be identified and documented in the HNF-SDW314-PICD-001, Project Interface Control Document Project W-314 Tank Farm Restoration and Safe Operations (PICD). The data in the PICD flows into the design specifications and media. 
RPP-6185, Rev. 0

\subsection{Configuration Management}

Configuration management of project generated and modified data will be in accordance with HNF-SD-W314-CM-001, Configuration Management Plan for Tank Farm Restoration and Safe Operations Project $W-314$ (CMP).

\subsection{Requirements Management}

The DRD and PDS requirements are stored in a W-314 database (Project W-314 Requirements Database) and managed in accordance with the project's CMP. The W-314 database currently uses the same RDD-100 software application as does the Hanford Site Technical Database (HSTD), linking W-314 requirements to architectures via functionality. Constraints are tied within the W-314 database directly to architectures.

The design baseline requirements, which are not directly from the project $\mathrm{DRD}$, will have their sources documented. This information will also be entered into the W-314 database for ease of requirements management. This database will use the same design as used previously by the project and will be controlled in the same manner. A traceability document may also be generated for each PDS to state where the requirements came from and/or how they were derived.

\subsection{Technical Reviews}

\subsubsection{Preliminary Design Reviews}

Procedure RPP-PRO-2000, Construction Program Execution Phase, Sec. 3.2.1.3, Periodic Reviews of Engineering and Design Activity, provides guidance for conducting Project W-314's preliminary reviews.

\subsubsection{Definitive Design Review}

Definitive Design Reviews will be conducted per the W-314 PEP and design verifications performed per HNF-IP-0842, Vol. 4, Sec. 4.24, Design Verification.

\subsection{SYSTEMS ENGINEERING PROCESS AND PRODUCTS}

\subsection{Systems Engineering Process}

A grading process was employed in accordance with the TWRS SEMP to determine which SE activities and deliverables are required of the project. Even though there is a single SE level for the project (level 1), the required activities and products were tailored for each end item based on complexity, mission criticality and safety significance. Required activities and deliverables are identified in Appendix A of this SEMP.

During the project's conceptual phase, the SE process derived requirements for four systems: the tank farm waste transfer, electrical, ventilation, and instrumentation and control systems. These requirements were rigidly tied and traceable to the upper level TWRS functional requirements and were documented in the WHC-SD-W314-DRD-001 Rev 0, June 1995. Through a number of assessments, W-314's scope has been refined and the DRD has been revised, accordingly. 
Architecture specific PDSs have been developed for W-314 Phase I design packages, and will also be developed for Phase 2 design packages. The PDSs have a sufficient level of detail to generate equipment designs. The PDS requirements shall include the appropriate W-314 DRD requirements. The process outlined below describes the process used to establish the new requirements during the requirements definition activity and also the process to be used to further develop the design baseline during definitive design activity.

\subsubsection{Mission Analysis}

A mission analysis was performed prior to the project's pre-conceptual phase and documented in WHC-SD-W314-MAR-001, Mission Analysis Report for Project W-314, Tank Farm Restoration and Safe Operations.

\subsubsection{Functions and Requirements Analysis and Allocation}

Project W-314 will analyze the equipment, as specified in Appendix A, to ensure each phase of the equipment's life cycle are considered during design.

The project will use the Functions, Requirements, Architecture and Test (FRAT) process for system requirements definition. However, since the scope elements provide modifications to existing systems, the functions and requirements will be derived as if the end item were an independent system with interfaces to the rest of the existing system. Requirements will be based on existing system requirements, new operational concepts and needs, and the existing DRD requirements as applicable. Requirements traceability will be established and/or maintained (see section 2.5). Derivations will be documented. The requirements analysis process will include, as appropriate:

a) identification of the points of interface the replacement items will have with the existing systems;

b) identification of the functions performed by the replaced item and definition of the required operational concept for the new item;

c) analysis of the required functionality for the replacement item, and its behavior when integrated into the existing system;

d) quantification of the required performance and interfaces.

The results of these activities will be documented in the PDSs, PICD, PDCs and requirements analysis documents/database to support definitive design. PDCs will be generated with the PDSs to communicate the design concepts to both designers and end users. 
Two PDCs exist for W-314 Phase 1:

- Waste Transfer Piping

- $\quad$ Master Pump Shutdown System

The Master Pump Shutdown PDC will be revised to include the Phase 2 scope related to instrumentation. The Master Pump Shutdown PDC will then be renamed "Monitoring and Control System". The Waste Transfer Piping PDC will be revised to also reflect the Phase 2 scope. One additional PDC is planned for Phase 2:

- $\quad$ DST Primary Ventilation System

\subsection{Major Products}

Many but not all of the products discussed in the following sections have been completed for Phase 1 of this project. As this SEMP applies to Phase 1 and 2, the text uses the future tense to include later activities.

\subsubsection{Integrated Baseline}

The integrated project baseline is the approved cost, scope, schedule and technical information used to define and manage the total project. This SEMP covers development of the DRD's subtier baseline.

\subsubsection{Cost, Scope and Schedule Baselines}

The cost, scope and schedule baselines for this project are specified in the W-314 PEP.

\subsubsection{Technical Baseline}

The top level project technical baseline has been documented in the HNF-SD-W314-DRD-001, Preliminary Design Requirements Document for Project W-314 Tank Farm Restoration and Safe Operations. The DRD identifies the TFRSO scope, system level functional, performance and Authorization Basis requirements. The subtier project technical baseline, lower level functional and requirement definitions are documented in the Project Development Specifications (PDS). The W-314 PDSs are:

- Transfer Piping, HNF-SD-W314-PDS-001

- Valve Pit Manifold, HNF-SD-W314-PDS-002

- Pit Leak Detection, HNF-SD-W314-PDS-003

- Master Pump Shutdown, HNF-SD-W314-PDS-004

- Special Protective Coating, HNF-SD-W314-PDS-005

- DST Primary Ventilation System (Phase 2, in preparation)

- Monitoring and Control System (Phase 2, in preparation, will include Master Pump Shutdown) 
The PDS requirements and associated data are stored and managed by incorporating them into the W-314 RDD-100 database.

\subsection{Design Baseline}

The project will produce and maintain the following design basis documents:

1) Design Requirements Document (DRD)

2) Project Development Specifications (PDSs)

3) Project Design Concept documents (PDCs)

4) Project Interface Control Document (PICD)

5) Piping and Instrumentation Diagrams (P\&IDs)

6) Design Drawings

7) Procurement/Construction Specifications

8) Safety Documentation

The technical baseline will be supported by architectural analyses, trade studies, specialty engineering studies, decision analyses, system assessment data and the facility authorization basis, as appropriate. The specific documents that will be generated, for the equipment in Project W-314's scope, are identified in Appendix A, "Project W-314 Graded Systems Engineering Approach Matrix".

\subsection{As-Built Baseline}

The project will update the design baseline products after the construction is complete in order to document the as-built system configuration as part of project closeout activities.

\subsubsection{Design Products}

The design activity will generate a definitive design based on the PDSs, PDCs and PICD. The output of this activity will include P\&IDs, design drawings, procurement specifications and construction specifications. The combination of these documents, along with the applicable supporting safety documentation, form the design baseline for each end item. The designs will be mostly based on Commercial Off-The-Shelf (COTS) equipment. Development of any significant new or unique items is not anticipated.

\subsubsection{Support Analysis}

Support analysis is an activity which focuses on overall support concepts for the operational equipment. The objective of this activity is to ensure the operational system is supportable throughout its life cycle. Evaluated areas generally include maintenance concepts, specialized support equipment requirements, supply support, etc. However, since the designs will primarily be replacement-in-kind or with similar technology to that already used on site, and will be based on COTS, it is believed that the existing Hanford support infrastructure is already set up to support such items. Also, COTS vendors will be required to provide (and normally do provide) required support data including recommended spares, special tools and support equipment, 
preventive and corrective maintenance, calibration, operations and maintenance procedures. Thus, the support analysis activities during this phase will focus on end item maintainability, reliability and determining site specific support constraints which influence design. The results of these activities will be documented in the PDSs.

\subsubsection{Verification and Validation (V\&V) Analysis}

Verification analysis focuses on determining what is required to prove that a design meets the requirements of its PDS. Validation analysis determines how the means of verification will be proven. These activities must also determine system testability, specialized equipment, facility and other resource requirements. It is important to determine early in the design activity what operational and maintenance testability features need to be designed into the equipment; and to determine if special test equipment is needed. The method of verification and the level of assembly for that verification will be documented in PDS section 4. The management approach and strategies will be documented in the HNF-SD-W314-TEP-001, Test and Evaluation Plan for Project W-314 Tank Farm Restoration and Safe Operations. The Test and Evaluation Plan (TEP) will integrate activities and resources across all design packages. Specific Test and Evaluation Plans (STEP) will be developed for each logical grouping of test and evaluation activities to communicate and document detailed T\&E planning, and will be identified per the TEP/STEPs.

\subsubsection{Installation and Start-up Analysis}

Installation and start-up analysis is an activity which focuses on understanding what is required to install, start-up and turn over new systems elements, and what constraints, if any, apply. This activity looks to understand special installation and start-up requirements, acceptance test requirements, operational test requirements, testability requirements associated with installation and start-up activities, equipment needs, and installation and start-up processes for each end item provided. It will also be used to establish installation and start-up strategies. It is important to determine early in the design activity if special installation/start-up equipment, item testability or processes are needed so they can be provided when needed. These activities will be performed during the design activity based on requirements provided by CHG's operations and system startup groups.

\subsubsection{Training Analysis}

Training analysis is an activity which focuses on understanding what special training, training facilities, equipment and materials will be required to ensure the work force can operate and maintain the new equipment in time to support operational testing and system turn-over. This activity identifies areas of required training, course work, equipment and special facility needs. This activity will be performed during the design activity by CHG. Any required equipment will be identified and added in the training section of the PDS.

\subsubsection{Decontamination and Decommissioning Analysis}

Decontamination and decommissioning (D\&D) analysis is an activity which provides an advanced look at D\&D concepts and constraints to determine impact on design. The only D\&D 
analysis considered necessary for this project is the search for design constraints imposed by law or regulation. Any identified will be included in the appropriate sections of the PDSs.

\subsubsection{Safety Analysis}

Safety analyses will be performed and documented in accordance with the W314 PEP.

\subsubsection{Alternative Generation and Architecture Selection}

System architecture will be defined using HNF-IP-0842, Vol. IV, Sec. 3.3, Alternative Generation and Analysis (AGA), where appropriate. HNF-IP-0842, Vol. IV, Sec. 2.7, Decision Management, will be used to select between alternative system configurations/technologies when AGAs are performed. The results will define end item configuration sufficiently to either enable any further requirements definition work or to enable design. The specific end items of this project which require AGAs are indicated in Appendix A.

\subsubsection{Evaluation and Optimization}

The project will evaluate feasible alternatives to the current project scope in order to optimize tank farm operations which cross its scope boundaries as opportunities are identified. Otherwise, solutions will be optimized within scope limits as part of the AGA process, when applied. Areas by which alternatives will be evaluated and optimized are, but not limited to:

1) technical feasibility/maturity;

2) risk;

3) life cycle cost;

4) reliability and maintainability;

5) testability;

6) schedule;

7) operability impacts;

8) system effectiveness;

9) other specialty engineering

These will be tailored to support the specific area of evaluation or optimization.

\subsubsection{Test and Evaluation}

See Sections 3.2.2.2 and 3.2.2.3 of this SEMP..

\subsection{Roles And Responsibilities}

Primary participating organizations and their general roles and responsibilities are identified in the W-314 PEP. The major participants involved in executing this SEMP, includes ORP, various organizations within the RPP, and the Design Agent as described in the W314 PEP. Design baseline document approval authority is summarized in Table 3-1. Other document approvals and responsibilities shall be per the $\mathrm{W}-314$ PEP. 
㐫

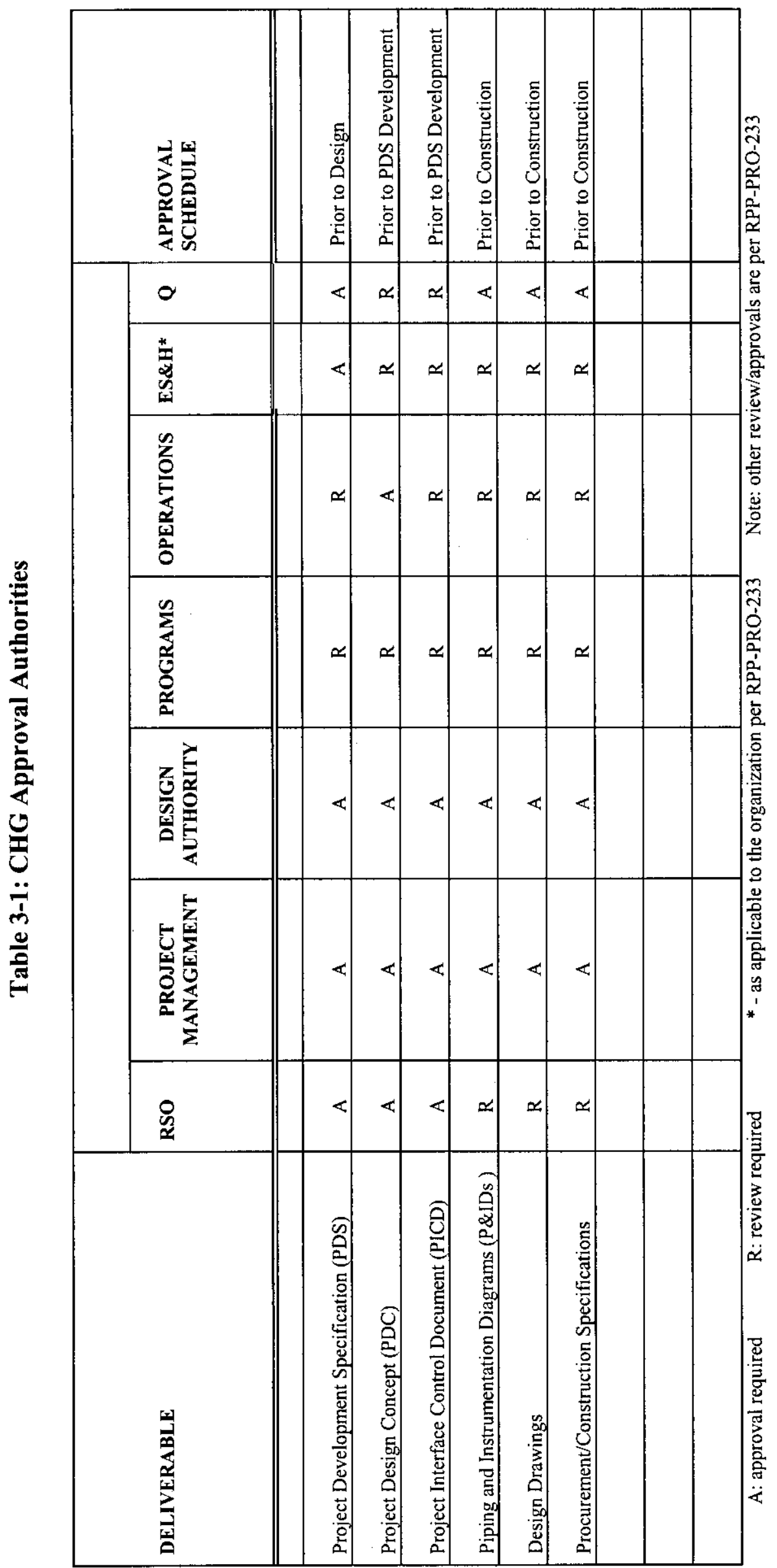




\subsection{REFERENCES}

The following documents are references which aid in understanding this SEMP.

DOE Order 430.1, August 24, 1995, Life-Cycle Asset Management

GPG-FM-001, March 1996, Project Management Overview

GPG-FM-002, March 1996, Critical Decision Criteria

GPG-FM-010, March 1996, Project Execution and Engineering Management Planning

GPG-FM-015, March 1996, Project Reviews

HNF 4903, Revision 0, Final Decision Report

HNF-IP-0842, RPP Administration, CHG, 1999

HNF-SD-W314-DRD-001, Preliminary Design Requirements Document for Project W-314 Tank Farm Restoration and Safe Operations

HNF-SD-W314-PDS-001, Revision 1, Transfer Piping

HNF-SD-W314-PDS-002, Revision 1, Valve Pit Manifold

HNF-SD-W314-PDS-003, Revision 1, Pit Leak Detection

HNF-SD-W314-PDS-004, Revision 2, Master Pump Shutdown

HNF-SD-W314-PDS-005, Revision 1, Special Protective Coating

HNF-SD-W314-PMP-001, Revision 3, Project Execution Plan for Tank Farm Restoration and Safe Operations, Project $W-314$

HNF-SD-W314-TEP-001, Revision 2, Test and Evaluation Plan for Project W-314 Tank Farm Restoration and Safe Operations

HNF-SD-WM-SEMP-002, Revision 0, Tank Waste Remediation System, Systems Engineering Management Plan

HNF-SD-WM-SEMP-002, Revision 1, Tank Waste Remediation System, Systems Engineering Management Plan

LMHC Memo \#73000-98-068, H.L. Boston, 7/15/98, Tank Waste Retrieval System Engineering Management Plan Implementation

WHC-SD-W314-MAR-001, Revision 0, Mission Analysis Report for Project W-314, Tank Farm Restoration and Safe Operations

RPP-PR0-1819, Engineering Requirements

RPP-PRO-2000, Construction Program Execution Phase 


\subsection{GENERAL INFORMATION}

\subsection{Notes}

\subsubsection{Document Descriptions}

The following paragraphs describe the purpose of selected documents mentioned in this SEMP.

\section{ALTERNATIVE GENERATION AND ANALYSIS (AGA)}

An AGA provides evaluation of system alternatives. The objective of this type of analysis is to enable selection of the system/technology which best satisfies mission needs/requirements based on criteria selected for optimization. It documents what different technical alternatives to system architectures and technologies were evaluated, the criteria used to evaluate them, and ranks the alternatives against those criteria.

\section{FUNCTION FLOW BLOCK DIAGRAMS (FFBDs)}

FFBDs are a means of diagramming required system behavior. They are generated during requirements definition activity in order to understand what a system must do with available input to achieve a required output. They are the means of documenting functional analysis which describes the relationships between required functions. They are useful for determining whether a set of functions are both necessary and sufficient to satisfy a mission or task within a mission; and to identify required functional inputs and outputs.

\section{PROJECT DEVELOPMENT SPECIFICATION (PDS)}

A PDS is a "design-to" specification detailing end item functional, performance, design, interface and verification requirements. It forms the basis for end item design. See Appendix B of this SEMP for W-314's PDS format and content descriptions, which can be used as applicable depending on the scope of the PDS.

\section{PROJECT DESIGN CONCEPT (PDC)}

A PDC contains the operational concepts, conceptual end item layouts or conceptual illustrations, user interface descriptions and any other qualitative information about the system. This document is used to communicate to designers and operators what the evolving operational and design concepts to design into the system. It also provides design guidance and the opportunity for early intervention into the direction the design is taking. This document is periodically updated as the design matures. This document will evolve into the System Description Document, after the design is completed and the end item installed.

\section{PROJECT INTERFACE CONTROL DOCUMENT (PICD)}

A PICD documents an agreement and approval regarding the physical interface between two end items. They contain a description of the physical characteristics which have been agreed upon by the owners of both sides of the interface. The interface data describes the type of interface, its required configuration (if known), and the amount, direction and nature of mass/energy which crosses the interface. Block diagrams can be included for clarification. This document forms a portion of the PDS by reference. 


\section{TEST AND EVALUATION PLAN (TEP)}

A TEP identifies all test and evaluation activities required by the project for design qualification, acceptance and operational start-up. It is used to identify, schedule and integrate the objectives and resources required for these activities.

\section{REQUIREMENTS ANALYSIS STUDY}

A traceability document identifies the basis for requirements in a PDS. It provides the derivation of requirement or points to the source where the requirement was pulled. This document is usually not required when a relational requirements database is used and an associated browser is available.

\section{REQUIREMENTS VERIFICATION REPORT (RVR)}

Documents the verification method for each PDS requirement and includes references to the document, calculation, test report etc. where the requirement compliance activity is recorded. 
RPP-6185, Rev. 0

\section{Appendix A: Graded Systems Engineering Approach For Project W-314}


0
0
0
0
0
0
0
0
0

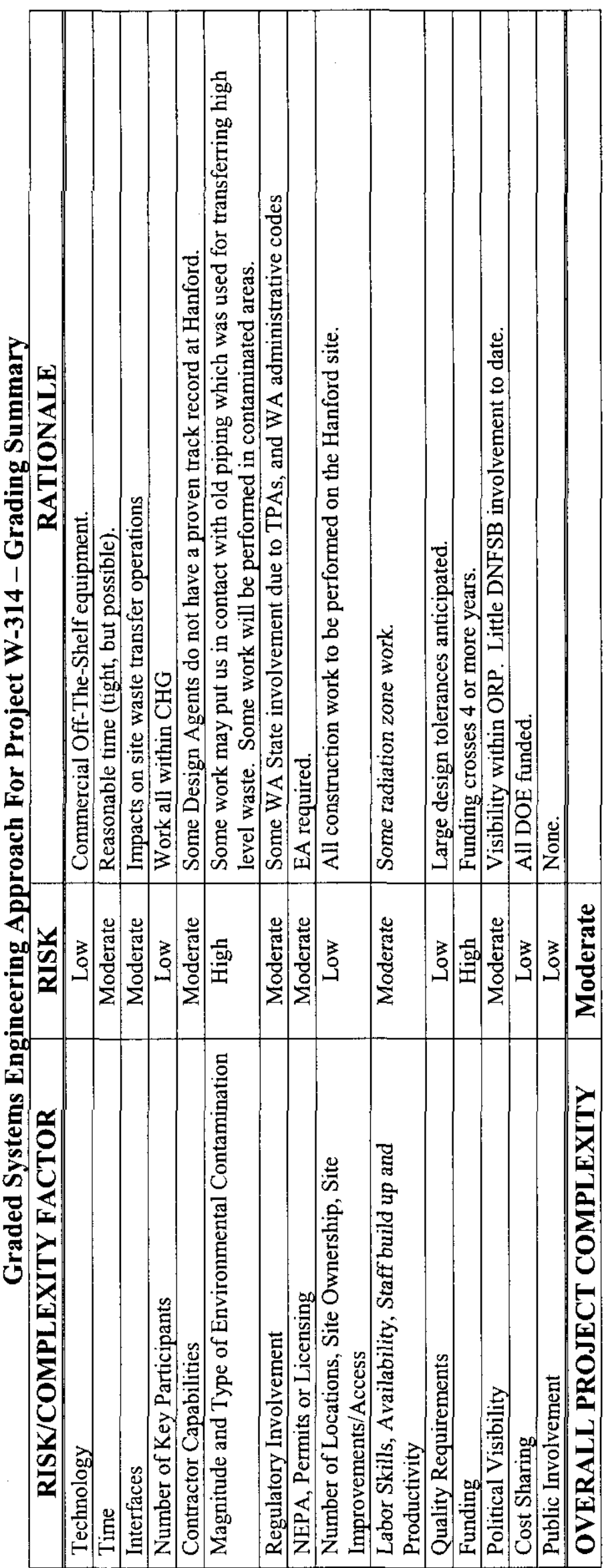




\begin{tabular}{|c|c|c|c|c|c|c|c|}
\hline \multirow{20}{*}{ 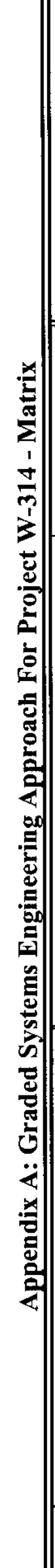 } & \multicolumn{2}{|l|}{$\sum_{\substack{\mid c \\
\sum}}^{\sum_{0}^{\infty}}$} & & 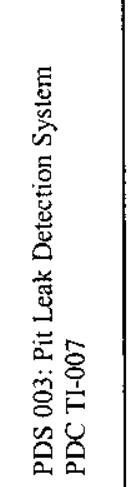 & 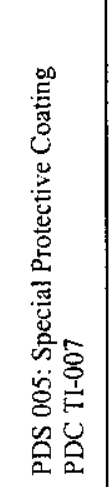 & 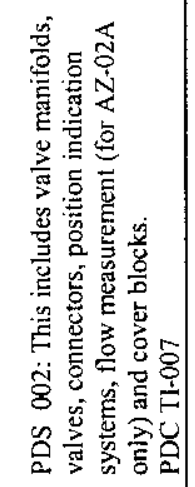 & 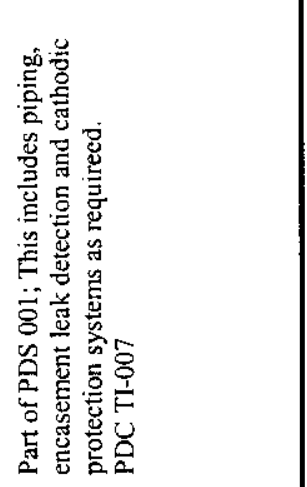 \\
\hline & \multirow{5}{*}{$\underset{⿱ 亠}{\infty}$} & $\theta \otimes \theta$ & & , & , & & \\
\hline & & $n=0.0 \%$ & & 0 & u & 0 & ن \\
\hline & & $H=\sigma .=\ldots=0$ & & . & . & $x$ & . \\
\hline & & $-\otimes \infty D$ & & $u$ & 0 & 0 & $u$ \\
\hline & & Har & & $x$ & $x$ & $x$ & $x$ \\
\hline & \multirow{12}{*}{ 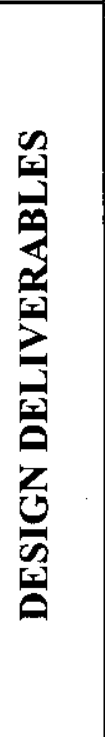 } & 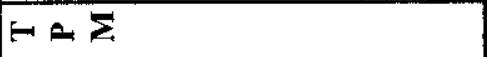 & & , & . & . & , \\
\hline & & 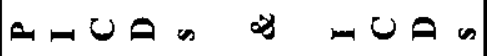 & & $x$ & $x$ & $x$ & $x$ \\
\hline & & Hคส & & $x$ & $x$ & $x$ & $x$ \\
\hline & & a s a d & & $x$ & $x$ & $x$ & $\times$ \\
\hline & & $n=00 \mathrm{cos}$ & & $x$ & $x$ & $x$ & $x$ \\
\hline & & $\theta \cdot n \cdot m=0 \leqslant \infty$ & & $x$ & $x$ & $x$ & $x$ \\
\hline & & 100 & & . & . & . & . \\
\hline & & $\Sigma-\infty m-0 \sum \infty$ & & 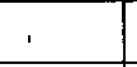 & i & 1 & 1 \\
\hline & & 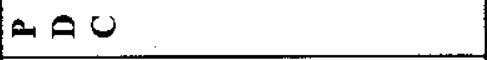 & & $x$ & $x$ & $x$ & $x$ \\
\hline & & 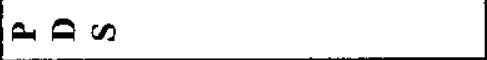 & & $x$ & $x$ & $x$ & $x$ \\
\hline & & $\varangle 0 \varangle$ & & 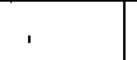 & . & , & . \\
\hline & & 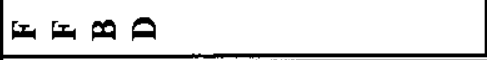 & & $x$ &. & $x$ & $x$ \\
\hline & $\begin{array}{l}\sum \\
= \\
E \\
0 \\
0 \\
0 \\
0 \\
0\end{array}$ & & 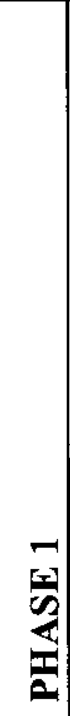 & 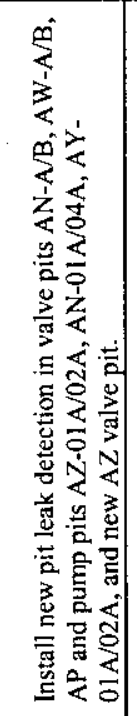 & 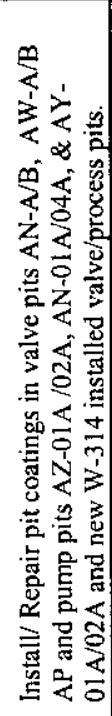 & 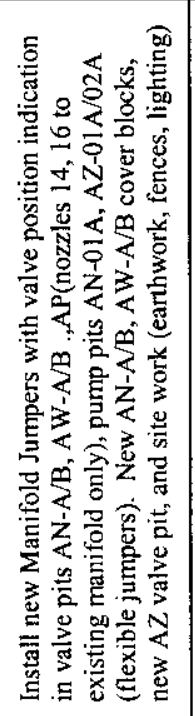 & 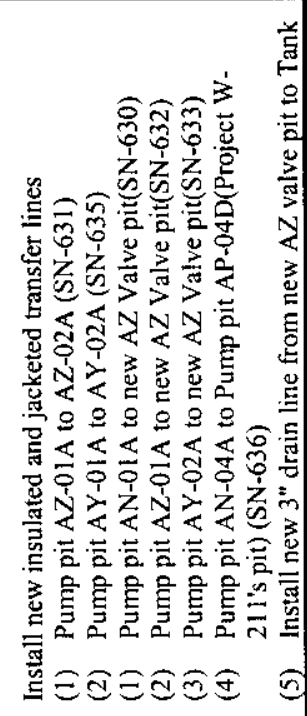 \\
\hline & & $\#$ & & $\overline{\bar{a}}$ & $\stackrel{\sim}{a}$ & $\frac{m}{2}$ & $\stackrel{\vec{a}}{\dot{2}}$ \\
\hline
\end{tabular}




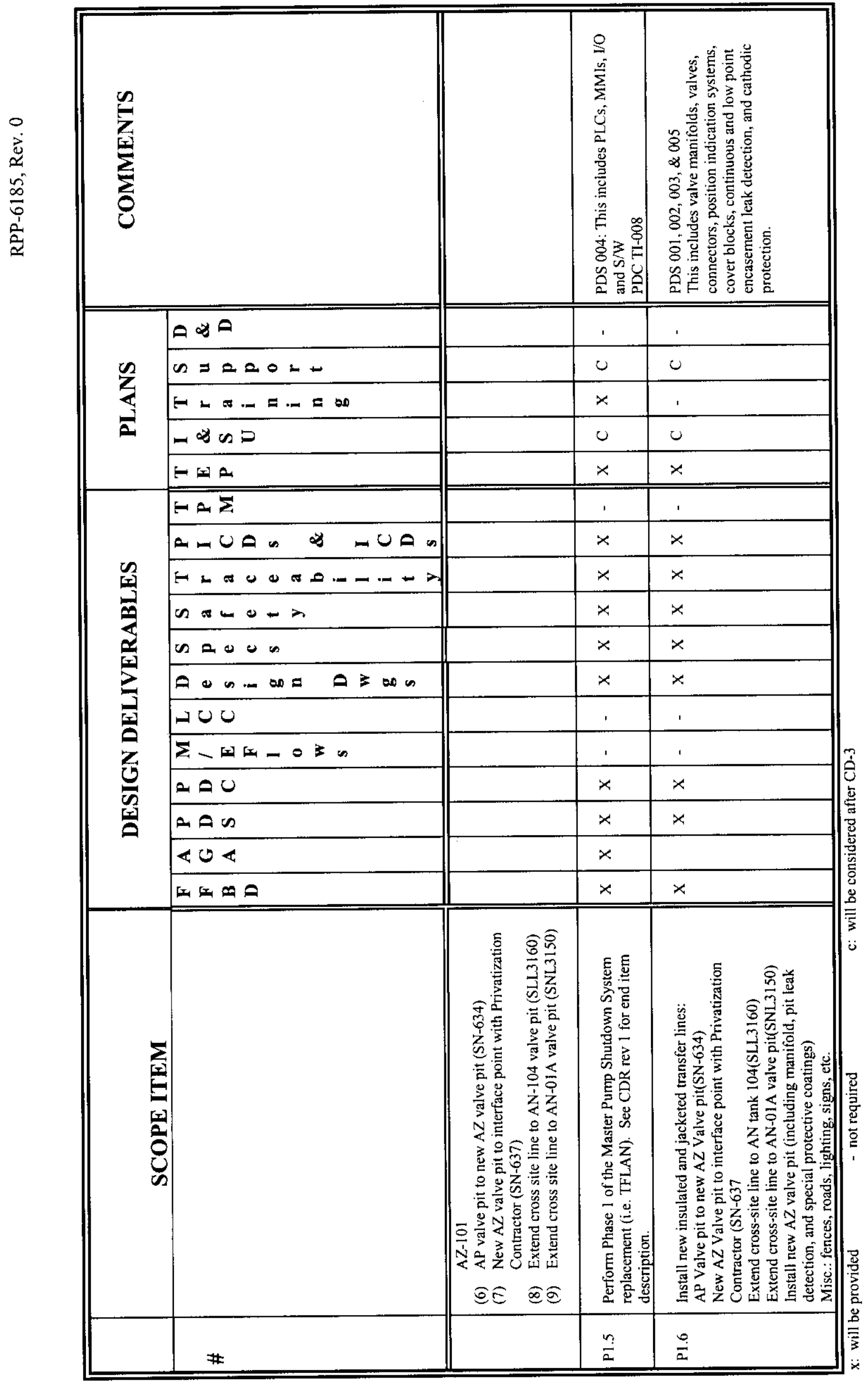




\begin{tabular}{|c|c|c|c|c|c|c|c|c|c|c|}
\hline & $\sum_{0}^{\sum_{0}^{\infty}}$ & & & 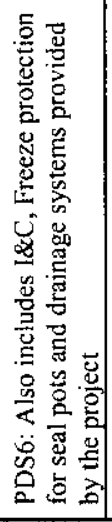 & 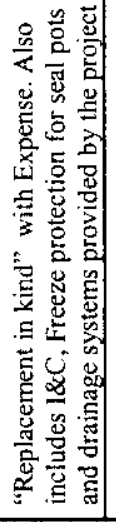 & 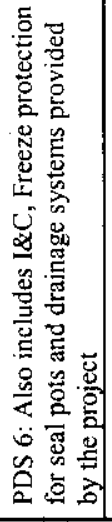 & & $\begin{array}{l}0 \\
0 \\
0 \\
0\end{array}$ & 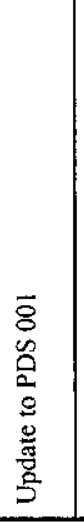 & \\
\hline \multirow{5}{*}{$\frac{\pi}{Z}$} & A & & & , & , & , & & . & , & \\
\hline & $n=000 \mathrm{~m}$ & & & 0 & 0 & $u$ & & $u$ & $u$ & \\
\hline & $H+a-a=00$ & & & $x$ & $\times$ & $x$ & & ' & . & \\
\hline & $-\otimes$ 电 & & & 0 & 0 & 0 & & 0 & 0 & \\
\hline & Ft tra & & & $x$ & $x$ & $x$ & & $x$ & $x$ & \\
\hline \multirow{12}{*}{ 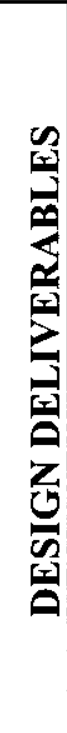 } & $\ln \Sigma$ & & & ' & & ' & & ' & ' & \\
\hline & 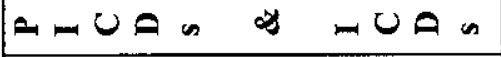 & & & $x$ & & $\times$ & & $x$ & $x$ & \\
\hline & $F m \pi 00 \pi=\ldots-\ldots$ & & & $x$ & & $x$ & & $x$ & $x$ & \\
\hline & $\infty \infty-\infty->$ & & & $x$ & $x$ & $x$ & & $x$ & $x$ & \\
\hline & $\infty a 00$ is & & & $x$ & $x$ & $x$ & & $x$ & $x$ & \\
\hline & $\theta \cdot n-\infty=a \geqslant \infty \infty$ & & & $x$ & $x$ & $x$ & & $\times$ & $x$ & \\
\hline & ט ن גו| & & & . & & . & & . & . & \\
\hline & $\Sigma$ - $15-0 \sum n$ & & & ' & & 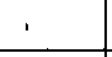 & & $\cdot$ & $\cdot$ & \\
\hline & $a 00$ & & & $x$ & & $x$ & & $x$ & $x$ & \\
\hline & an & & & $x$ & & $x$ & & $x$ & $x$ & \\
\hline & $<0<$ & & & & & $x$ & & . & ' & \\
\hline & ๘のの & & & $x$ & & $x$ & & . & $x$ & \\
\hline & 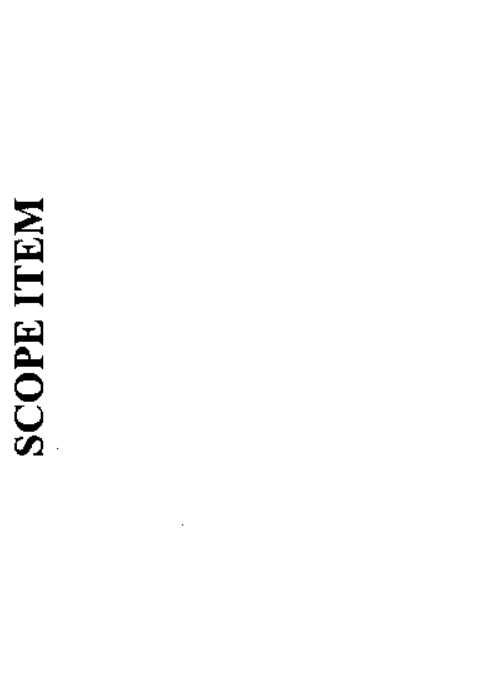 & $\begin{array}{l}N \\
\frac{5}{5} \\
0\end{array}$ & 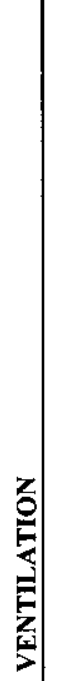 & 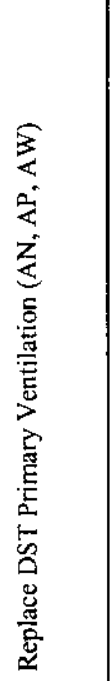 & 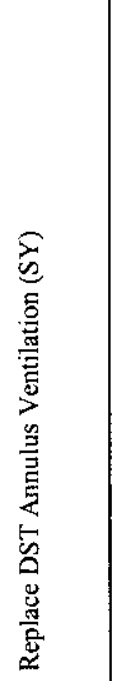 & 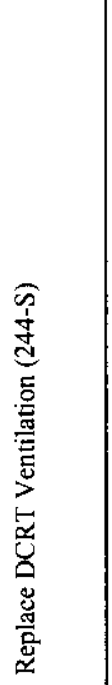 & $\begin{array}{l}\vec{z} \\
\vec{\Delta} \\
\mathbf{a}\end{array}$ & 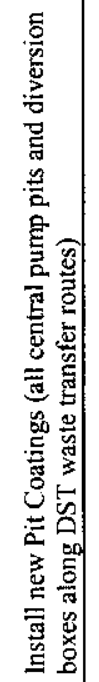 & 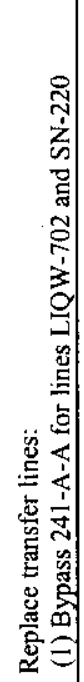 & \\
\hline \# & & & $\stackrel{0}{>}$ & $\overline{7}$ & $\stackrel{?}{>}$ & $\stackrel{m}{>}$ & $\stackrel{\circ}{\circ}$ & $\overline{\omega_{i}}$ & $\stackrel{\sim}{a}$ & \\
\hline
\end{tabular}




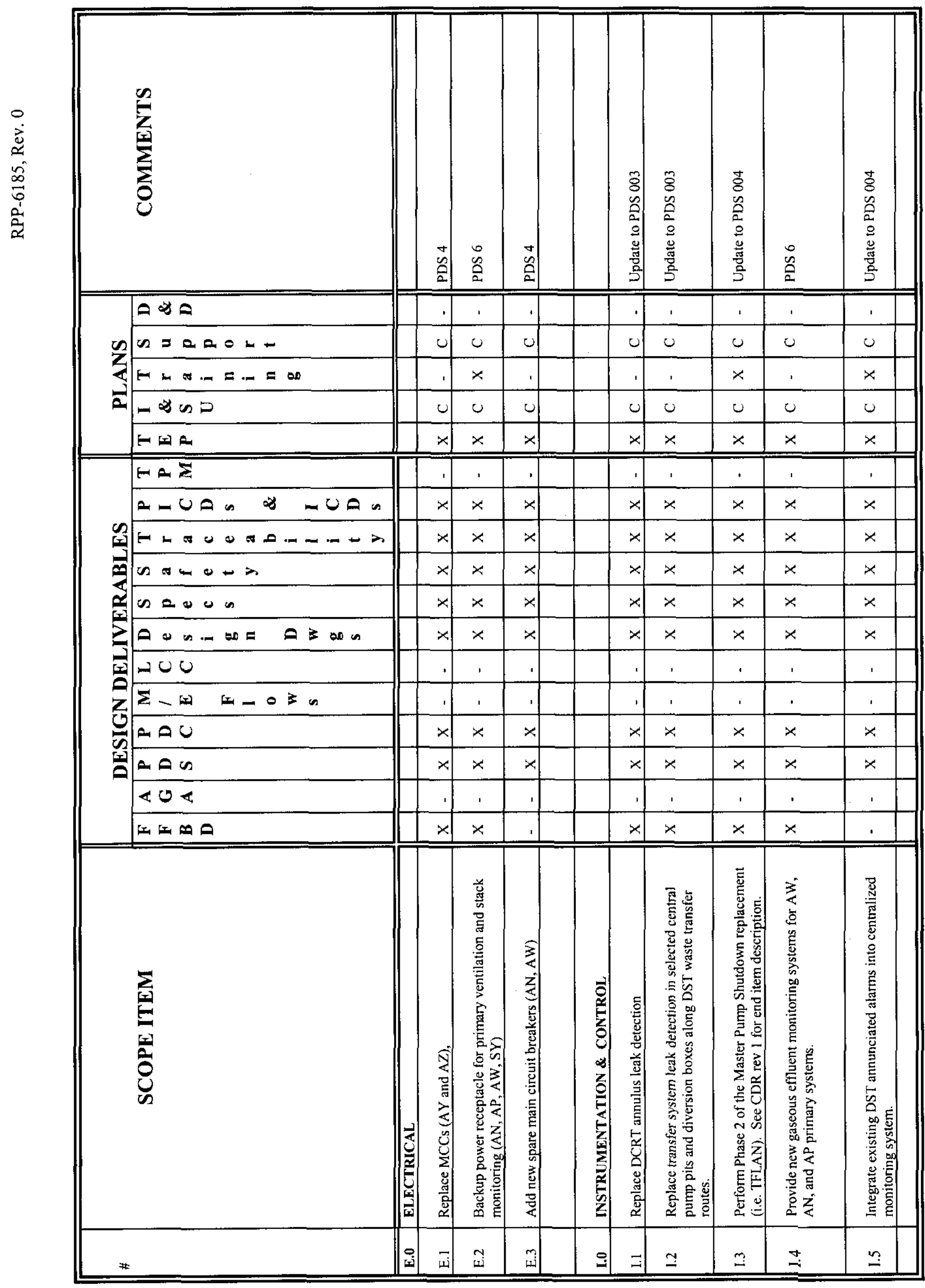




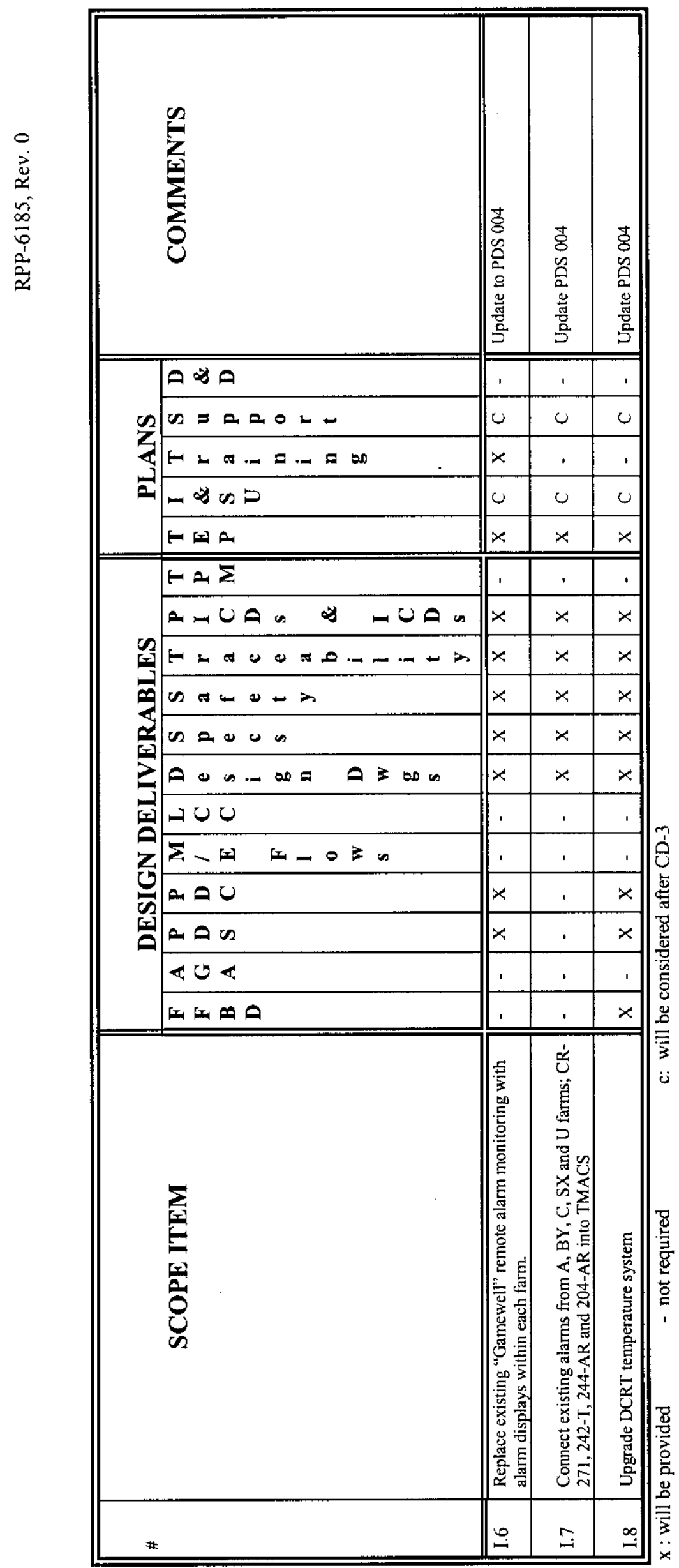

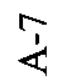


RPP-6185, Rev. 0

Appendix B Project Development Specification (PDS) Standard For Project W-314 


\title{
Project Development Specification
}

\author{
for
}

\section{"Subsystem's Name"}

Project W-314

Tank Farm Restoration and Safe Operations

CH2M HILL Hanford Group

Prepared by:

Date

Concurrence:

Date

Concurrence:

Date

Concurrence:

Date

Concurrence:

Date 


\section{Table of Contents}

1.0 SCOPE

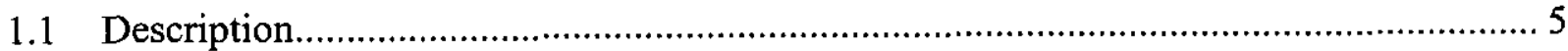

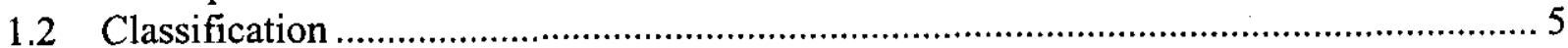

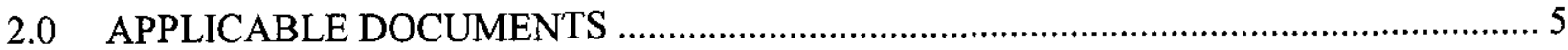

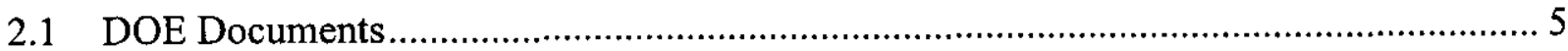

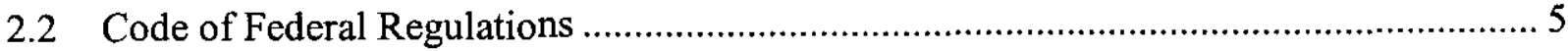

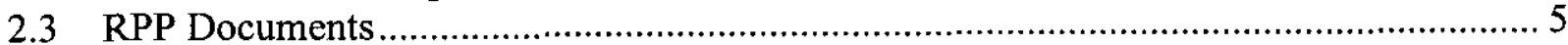

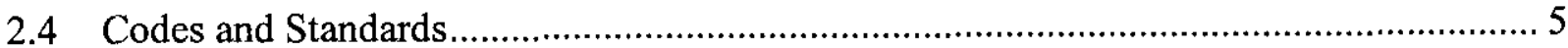

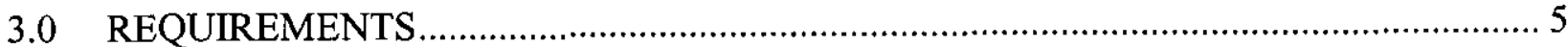

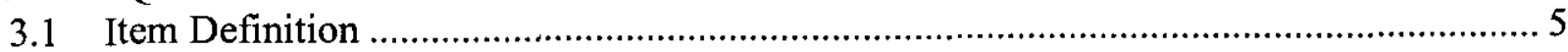

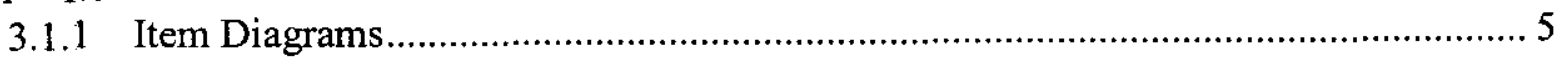

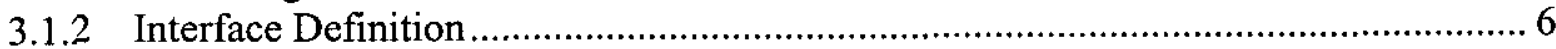

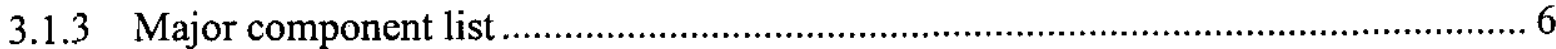

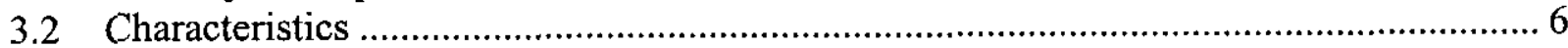

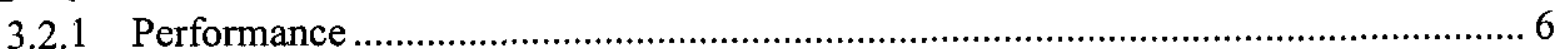

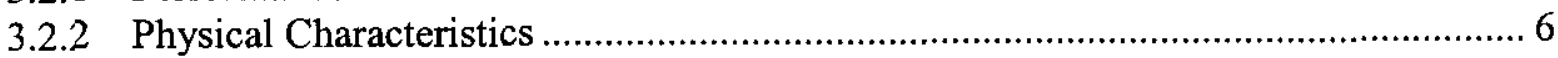

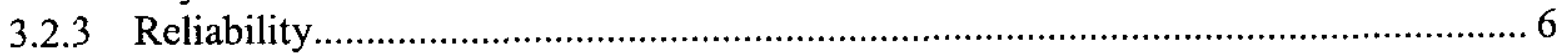

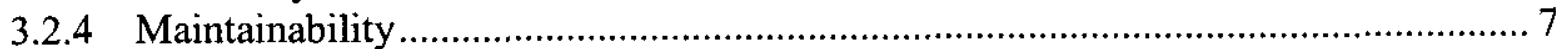

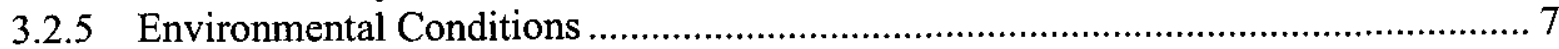

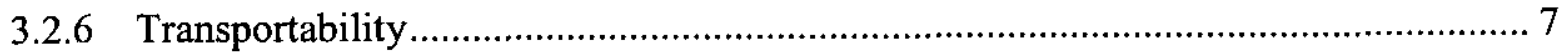

3.3 Design and Construction .......................................................................................... 7

3.3.1 Materials, processes, and parts........................................................................... 7

3.3.2 Electromagnetic radiation ..................................................................................... 7

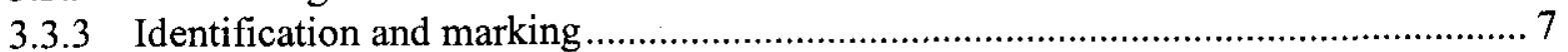

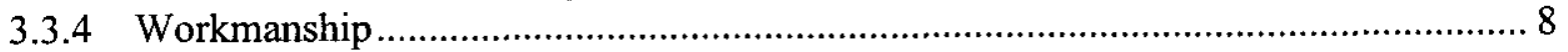

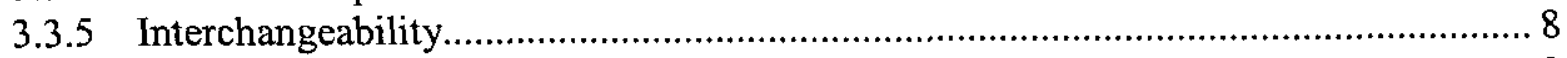

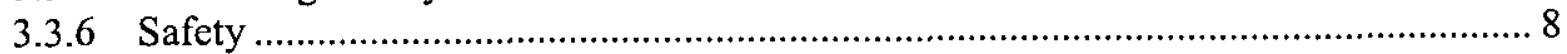

3.3.7 Human performance/human engineering …….................................................... 8

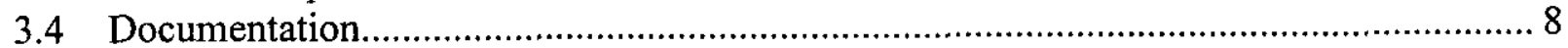

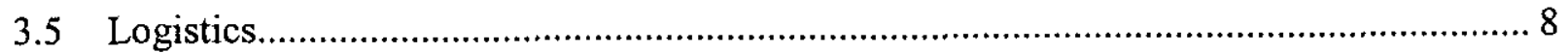

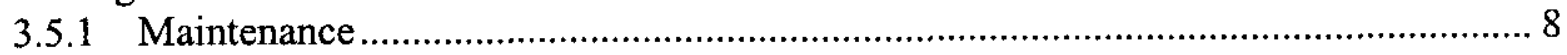

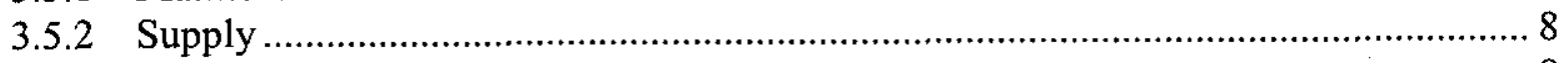

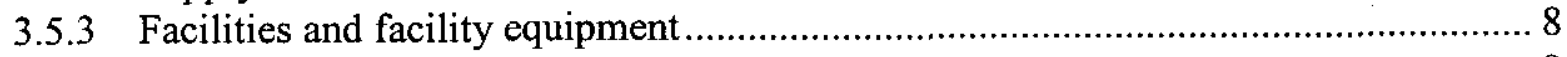

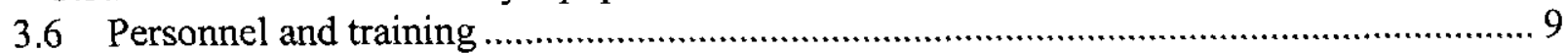

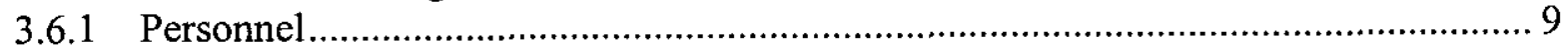

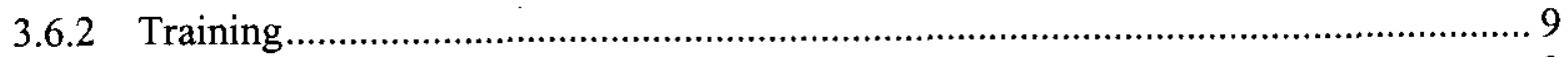

3.7 Major Component Characteristics ................................................................................

4.0 SYSTEM QUALIFICATION PROVISIONS …….........................................................

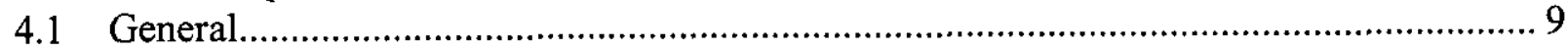

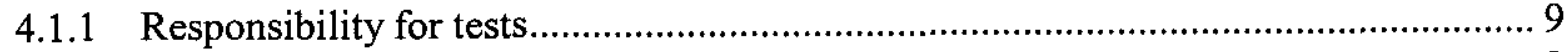

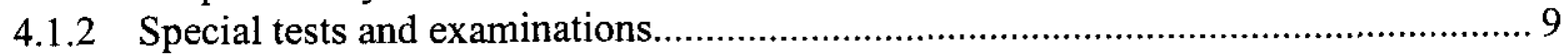

4.2 Quality conformance verification ............................................................................... 10

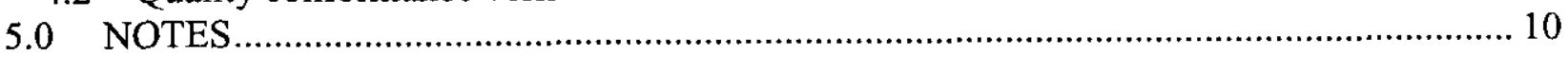




\section{Acronym List}

$\begin{array}{ll}\text { AASHTO } & \text { American Association of State Highway and Transportation Officials } \\ \text { ALARA } & \text { as low as reasonably achievable } \\ \text { AREA } & \text { American Railway Engineering Association } \\ \text { ASCE } & \text { American Society of Civil Engineers } \\ \text { ASME } & \text { American Society of Mechanical Engineering } \\ \text { ASTM } & \text { American Society for Testing and Materials } \\ \text { CFR } & \text { Code of Federal Regulations } \\ \text { DBA } & \text { design basis accident } \\ \text { DBE } & \text { design basis earthquake } \\ \text { DCRT } & \text { Double Contained Receiver Tank } \\ \text { DOE } & \text { U.S. Department of Energy } \\ \text { DRD } & \text { design requirements document } \\ \text { DST } & \text { double shell tank } \\ \text { HLW } & \text { high level waste } \\ \text { NACE } & \text { National Association of Corrosion Engineers } \\ \text { PGV } & \text { peak ground velocity } \\ \text { PICD } & \text { project interface control drawing } \\ \text { SDC } & \text { Hanford site design criteria } \\ \text { SL } & \text { line designation for slurry piping } \\ \text { SN } & \text { line designation for supernate piping } \\ \text { TEDE } & \text { total effective dose equivalent } \\ \text { TFRSO } & \text { Tank Farm Restoration and Safe Operations } \\ \end{array}$




\subsection{SCOPE}

\subsection{Description}

This specification establishes the performance, design development, and test requirements for (insert the physical item's name and identifier). The purpose of this paragraph is to describe the item that will be further detailed in the remainder of this spec. Describe what the item is in this paragraph. This brief statement shall be sufficiently complete and comprehensive to describe generally the item and material or process covered by the specification in terms that may be easily interpreted by manufacturers, contractors, etc. Do not list requirements that belong appropriately elsewhere in this spec.

\subsection{Classification}

Where a spec covers more than one category of an item, designations of classification such as types, grades, classes, etc. shall be listed under this heading and shall be in accordance with accepted industry practice. When only one class of the item is covered by this spec then the classification statement will be written in the scope paragraph and this section deleted. When the terms type, class, grade, composition, and style do not serve accurately to classify the differences, then other terms such as color, form, weight, size temperature rating, etc. suitable for reference may be used.

\subsection{APPLICABLE DOCUMENTS}

List all and only those documents referenced in Section 3, 4, 5, and Appendixes of this spec. and should include title and date or rev.

\subsection{DOE Documents}

\subsection{Code of Federal Regulations}

\subsection{RPP Documents}

\subsection{Codes and Standards}

\subsection{REQUIREMENTS}

\subsection{Item Definition}

This paragraph will graphically portray the functions of the item and the relationship of the item to be developed to the remainder of the system. It shall identify (a) the major components of this item and (b) the individual components which must be developed.

\subsubsection{Item Diagrams}

This paragraph will display the item level functional schematics. This paragraph will cover the top-level functional flow diagrams of the item and include diagrammatic presentations to the level required to identify all essential functions 


\subsubsection{Interface Definition}

This paragraph shall cover the functional and physical interfaces between (a) this item and the other items, and (b) the major components within this item. The functional interfaces shall be specified in quantitative terms of input/output voltages, temperature ranges, loads, velocities, etc. Where interfaces differ due to a change in operational mode, the requirements shall be specified in a manner which identifies specific functional interface requirements for each different mode. Physical interface relationships shall be expressed in terms of dimensions with tolerances.

\subsubsection{Functional Interfaces}

\subsubsection{Physical Interfaces}

\subsubsection{Major component list}

This paragraph shall include a complete list of all major components which comprise the item

\subsection{Characteristics}

\subsubsection{Performance}

This paragraph shall state what the item shall do, including upper and lower performance limits. Include considerations such as: rates, velocities, pressure, etc. and quantitative criteria covering the endurance capabilities of the item required to meet user needs under stipulated environmental and other conditions, including minimum total life expectancy. Indicate required mission duration and planned utilization rate.

\subsubsection{Physical Characteristics}

This paragraph shall include the following as applicable:

a) Weight limits of the item

b) Dimensional and cube limitations, operator station layout, ingress, egress, and access for maintenance.

c) Requirements for transport and storage, such as tiedowns, pallets, packaging, and containers.

d) Durability factors to indicate degree of ruggedness.

e) Health and Safety criteria, including consideration of adverse explosive, mechanical, and biological effects. Included in these criteria are the toxicological effects of the item or components thereof on the user.

f) Security criteria

g) Command control requirements.

h) Vulnerability factors including consideration of chemical, biological, and radiological operations, electromagnetic radiation, fire, and impact.

\subsubsection{Reliability}

Reliability shall be stated in quantitative terms, defining the conditions under which the requirements are to be met. Reliability requirements are normally expressed in terms of the required Mean Time Between Failure, i.e. 10,000 operating hours between failures. 
Reliability can also be expressed as a percentage availability, i.e., operational $90 \%$ of a time period, $90 \%$ of the time during transfers, etc.

\subsubsection{Maintainability}

This paragraph shall specify the quantitative maintainability requirements. The requirements shall apply to maintenance in the planned maintenance and support environment and shall be stated in quantitative terms. Examples are:

a) Time (e.g., mean and maximum downtime, reaction time, turnaround time, mean and maximum time to repair, mean time between maintenance actions).

b) Rate (e.g., maintenance manhours per operational hours, maintenance manhours per specific maintenance action, operational ready rate, frequency of preventive maintenance).

c) Maintenance complexity (e.g., number of people and skill levels, variety of support equipment).

\subsubsection{Environmental Conditions}

This paragraph shall include both induced and natural environmental conditions expected to be encountered by this item during storage, shipment, and operation. It shall include such factors as climate, shock, vibration, noise, and noxious gases.

\subsubsection{Transportability}

This paragraph shall include requirements for transportability which are common to all components to permit receipt, deployment and logistic support. Any item/component which due to it functional or operational characteristics, will be unsuitable for normal transportation methods shall be identified.

\subsection{Design and Construction}

This paragraph shall specify minimum item design and construction standards which have general applicability and are applicable to major classes of equipment or are applicable to particular design standards (e.g., nuclear air handling systems, piping standards, etc.). To the maximum extent possible, these requirements shall be specified by reference to the established government and industry specifications and standards.

\subsubsection{Materials, processes, and parts}

This paragraph shall specify those item-particular requirements governing use of materials, parts, and processes to be used in the design of the item. It shall also provide information on which materials, processes and parts that are not acceptable for use.

\subsubsection{Electromagnetic radiation}

This paragraph shall contain requirements pertaining to electromagnetic radiation. It shall cover both the environment in which the item operates as well as that which it generates.

\subsubsection{Identification and marking}

This paragraph shall contain requirements for nameplates, part marking, serial and lot number marking, and all other identifying markings required for the item and its component parts. 


\subsubsection{Workmanship}

If development models of equipment are to be used during design, this paragraph shall contain the workmanship requirements for producing the models.

\subsubsection{Interchangeability}

This paragraph shall identify those components to be interchangeable and replaceable. Entries in this paragraph are for the purpose of establishing a condition of design.

\subsubsection{Safety}

This paragraph shall specify requirements to preclude or limit hazards to personnel and equipment. To the extent practicable, these requirements shall be imposed by citing established and recognized standards. Limiting safety characteristics peculiar to the item due to hazards in assembly, disassembly, test, transport, storage, operation or maintenance shall be stated when covered neither by standard industrial or service practices. "Fail-safe" and emergency operating restrictions shall be included where applicable. These shall include interlocks and emergency standby circuits required to either prevent injury or provide for recovery of the item in the event of failure.

\subsubsection{Human performance/human engineering}

Human engineering requirements for the configuration of the item should be specified herein and applicable documents included by reference. This paragraph should also specify any special or unique requirements.

\subsection{Documentation}

This paragraph shall specify the plan for item documentation such as: specifications, drawings, technical manuals, test plans and procedures, installation instruction data.

\subsection{Logistics}

\subsubsection{Maintenance}

This paragraph shall include considerations such as: use of multipurpose test equipment, use of module vs. part replacement, maintenance and repair cycles, accessibility and level of repairablility.

\subsubsection{Supply}

This paragraph shall specify the impact of the item on the supply system and the influence of the supply system on the item design and use. Considerations shall include: introduction of new components into the supply system, supply and resupply methods, distribution and location of item stocks.

\subsubsection{Facilities and facility equipment}

This paragraph shall specify the impact of the item on existing facilities and facility equipment. It also shall specify requirements for new facilities or ancillary equipment to support the item. 


\subsection{Personnel and training}

\subsubsection{Personnel}

This paragraph shall specify personnel requirements which must be integrated into the item design. Requirements shall be specified in a positive sense, assuming that the numbers and skill levels of personnel will be made available. Requirements shall be the basis for determination of item personnel training equipment/facility requirements.

\subsubsection{Training}

This paragraph shall consider: a.) Training requirements that will be generated by new equipment to include, if possible, the concept of how training should be accomplished, e.g., school, unit, or contractor training. b.) Estimates of quantities of equipment being developed that will be required solely for training purposes. c.) The need to develop associated training devices, including types required. Prepare actual detailed statements of requirements for characteristics of training devices. d.) Training time and locations available for effective training programs.

\subsection{Major Component Characteristics}

This paragraph shall include a subparagraph for each major component listed in paragraph 3.1.3. In stating requirements for the various major components, it should be recognized that verification may necessarily need to be accomplished following the delivery, installation, and checkout of the parts constituting the major components. The functional relationship may be such that verification of requirements specified for a major component can only be accomplished when the units, assemblies; or parts which comprise the major component are assembled into the item. For each major component, a separate paragraph shall be prepared specifying the performance and physical characteristics.

\subsection{SYSTEM QUALIFICATION PROVISIONS}

\subsection{General}

This paragraph specifies:

The Project's Quality Assurance Program Plan (QAPP) defines the quality assurance requirements for the Project; the verifications identified Section 4.2.1, may be performed in conjunction with the QAPP verifications; and the inspections identified in 4.2.1, are to be performed in accordance with the Project's Test and Evaluation Plan (TEP).

\subsubsection{Responsibility for tests}

This paragraph references the Project's Project Execution Plan for responsibilities.

\subsubsection{Special tests and examinations}

This paragraph is optional in the development specification, and when used, would generally cover testing requirements for qualification evaluation for selection of parts, components, or equipment to be used in the system. 


\subsection{Quality conformance verification}

This paragraph provides definitions for "Test", "Demo", "Exam", and "Anal" for the "Inspection Element" column described in Section 4.2.1, "Quality Conformance Inspection Matrix".

\subsubsection{Quality conformance Inspection Matrix}

This section provides a table, which identifies the Inspection Element(s) assigned to verify the equipment being provided by the Project will adequately perform the requirements defined in Section 3 of the PDS.

\subsection{NOTES}

The contents of this section are not contractually binding, but provide for background information, notes, etc. 


\section{DISTRIBUTION SHEET}

To

Distribution

Project Title/Work Order

W-314, Tank Farm Restoration and Safe Operations

\begin{tabular}{|l|l|}
\hline \multicolumn{1}{|c|}{ Name } & \\
\hline J.B. Bailey & \\
\hline D.E. Bowers & \\
\hline T.J. Volkman & \\
\hline T.E. Nugent & \\
\hline J.L. Gilbert & \\
\hline C.B. Bryan & \\
\hline R.W. Root & \\
\hline D.L. McGrew & \\
\hline B.L. Syverson & \\
\hline J.W. Lentsch & \\
\hline R.J. Eogg & \\
\hline M.E. Erhart & \\
\hline K.B. Ferlan & \\
\hline R.R. Bevins & \\
\hline D.E. Legare & \\
\hline O.D. Nelson & \\
\hline J.D. Guberski & \\
\hline C.A. Burke & \\
\hline N.K. Butler & \\
\hline & \\
\hline Project Files & \\
\hline Project Library & \\
\hline & \\
\hline
\end{tabular}

From
TER\&SO

\begin{tabular}{|l|l|} 
Page 1 of 1 \\
\hline Date \\
\hline EDT No 628193 \\
\hline ECN No. \\
\hline
\end{tabular}

\begin{tabular}{|c|c|c|c|c|}
\hline MSIN & $\begin{array}{c}\text { Text } \\
\text { With All } \\
\text { Attach. }\end{array}$ & Text Only & $\begin{array}{l}\text { Attach./ } \\
\text { Appendix } \\
\text { Only }\end{array}$ & $\begin{array}{c}\text { EDT/ECN } \\
\text { Only }\end{array}$ \\
\hline
\end{tabular}

\begin{tabular}{l|r}
$\mathrm{R} 3-25$ & $\mathrm{X}$ \\
$\mathrm{S} 5-13$ & $\mathrm{x}$ \\
$\mathrm{R} 3-25$ & $\mathrm{x}$
\end{tabular}

R3-25

S5-50

R3-25

$\mathrm{R} 2-58$

R3-53

R3-25

G3-12

R3-25

$55-12$

R $3-25$

R3-25

R3 -25

R3 -25

R3-25

R1-51

R3-25

R3-25

$\frac{x}{x}$

$\frac{x}{x}$

$x$

$x$

$x$

$x$

